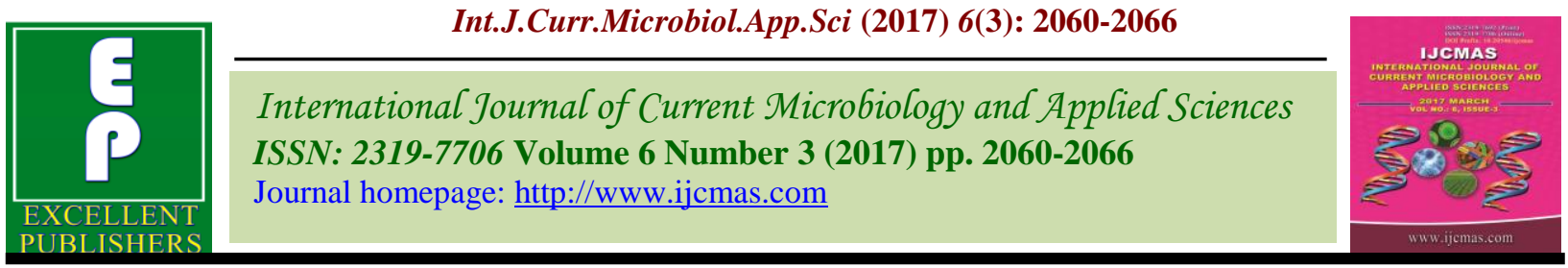

Original Research Article https://doi.org/10.20546/ijcmas.2017.603.235

\title{
Furfural and 5-HMF: Potent fermentation inhibitors and their removal techniques
}

\author{
Mahesh Kumar Malav ${ }^{1}$, Shiv Prasad ${ }^{1}$, Sushil Kumar Kharia ${ }^{2}$, \\ Sandeep Kumar ${ }^{1}$, K.R. Sheetal ${ }^{1}$ and Sudha Kannojiya ${ }^{1}$ \\ ${ }^{1}$ Centre for Environmental Science and Climate Resilient Agriculture, Indian Agricultural \\ Research Institute, PUSA, New Delhi 110012, India \\ ${ }^{2}$ Division of Agricultural Physics, Indian Agricultural Research Institute, \\ PUSA, New Delhi 110012, India \\ *Corresponding author
}

A B S T R A C T

The objective of this study to find out the effect of ketamine in combination of opioids on haemodianamics and electrocardiograph in dogs.The ketamine hydrochloride @3mg/kg bwt was administered epidurally at lumbosacrcal space in group I, whereas buprenorphine @ $0.005 \mathrm{mg} / \mathrm{kgbwt}$, pentazocine @ $0.3 \mathrm{mg} / \mathrm{kg}$ bwt and meperidine hydrochloride (@1 $\mathrm{mg} / \mathrm{kgbwt}$ were given epidurally in combination with ketamine hydrochloride in group II, III and IV, respectively.To accomplish epidural block, an 18-gauge $3.5 \mathrm{~cm}$ hypodermic needle was inserted percutaneously at the prepared site into the epidural space to inject analgesic agent. Haemodynamic and electrocardiographic changes were recorded before and at the time intervals of 5, 15,30,60 and minutes of ketamine administration. Haemodyanamic parameters viz. heart rate, systolic arterial pressure, diastolic arterial pressure and mean arterial pressure showed a significant higher $(\mathrm{P}<0.05)$ value at initial intervals of observation, thereafter, the values revealed a decreasing trends and returned to base line value by the end of observation. Shortening of PR, R.R. and QT intervals were recorded at $5 \mathrm{~min}$ up to $30 \mathrm{~min}$. in all the groups. The QRS complex did not show significant variation among and between group. In conclusion, Ketamine in combination of buprenorphine, pentazocine and meperidine as epidural anaesthesia in dogs was found to be effective and produces reversible changes on haemodynamics and Electrocardiograph.

\section{Introduction}

The increased concern for energy security and the negative impact of fossil fuels on the environment, particularly air pollution and greenhouse gas emissions, has put pressure on society to find new renewable fuel alternatives.Ethanol is currently one of the most promising alternatives to conventional transport fuels because of its desirable characteristics such as high octane value and good combustion efficiency. The Ministry of New and Renewable Energy (MNRE, 2009), Govt. of India has estimated that about 500 Mt of crop residues are generated every year. So, there is a vast scope for converting lignocellulosic biomass into bio-ethanol in India. Also, the use of ethanol produced from biomass as a transport fuel can help in reducing $\mathrm{CO}_{2}$ buildup in atmosphere by 
recycling $\mathrm{CO}_{2}$ that is released when bioethanol is combusted as fuel (Hasunuma and Kondo, 2012). The microbial conversion of lignocellulosic biomass into ethanol is attracting increasing interest; this is due to the fact that ethanol is an excellent alternative energy fuel for the future and produces very low amount of greenhouse gases on burning.

Producing ethanol from biomass has proven to be a challenging process on multiple fronts. Biomass is inherently recalcitrant to enzymatic and microbial attack, which necessitates a pretreatment to make the crystalline cellulose in the lignocellulosic substrate more available for enzymatic hydrolysis (Binod et al., 2010). To complicate the matter further,some microbial inhibitors are also released during pretreatment of biomass, which affects fermentation performance of microbes. These inhibitors are formed when pretreatment conditions are too severe. Among the inhibitory byproducts,furfural and 5-hydroxy methyl furfural (Fig. 1) are the most potent inhibitory compounds generated from acid pretreatment of lignocelluloses to simple sugars for fermentation (Zaldivar et al., 1999).

Biomass pretreatment using acid hydrolysis generates inhibitory compounds, which interfere with the subsequent fermentation. Among more than 100 compounds detected, furfural and 5-hydroxymethyl furfural (HMF) are the most potent and representative inhibitors (Luo et al., 2002; Martin and Jonsson, 2003). The inhibitory byproducts formed by pretreatment of lignocelluloses depend on both the biomass and the pretreatment conditions such as temperature, time, pressure, $\mathrm{pH}$, redox conditions and addition of catalysts.

In high temperature pretreatment, the formation of fermentable carbohydrates and degradation products is dependent on a combined severity factor, including reaction temperature, time and $\mathrm{pH}$ (Tengborg et al., 1998). Sugar degradation products i.e. furfural (frompentoses) and 5-hydroxylmethyl furfural (from hexoses) are formed in high concentrations during severe acidic pretreatment conditions (Taherzadeh et al., 1997). The formation of inhibitors and consequently of toxic compounds is a problem, that has a negative fallout on the rate of enzymatic hydrolysis. Table 1 summarizes the inhibitors profile derived from variety of lignocellulosic materials.

Aromatic degradation products from sugar degradation are predominantly furans: 2furfural, 5-hydroxyl methyl furfural, 2-furoic acid and to minor extent phenols formed by solubilization and hydrolytic or oxidative cleavage of lignin. The concentrations of these aromatic compounds in hydrolysates arealso dependent on the type of pretreatment and ratio of the lignin contained in the biomass material.

\section{Quantification of inhibitors}

Different analytical methods were developed in the last years to determine furfural compounds in environmental and food samples. These methods initially were spectrophotometric measurements $(\mathrm{Tu}$, D.,1992).Because these methods are time consuming and not specific, HPLC and gas chromatography were used as rapid and selective methods for determination of these compounds in environmental and food samples(Ferrer, et al., 2002;Servin, et al., 2005).

\section{Effect of inhibitory by-products on microbial strains}

Microorganisms differ in their ability to adapt and grow in the hydrolysates. The fermentative performances of microorganisms 
in lignocellulosichydrolysates depend on raw material and pretreatment (Olsson and HahnHagerdal, 1996). There are several measures of fermentability: growth, ethanol yield, ethanol productivity and specific ethanol productivity that should be taken into account when performing experimentation and industrial production (Hahn-Hagerdal et al., 1994).Most ethanol fermenting yeasts, including industrial strains, are susceptible to various inhibitory compounds derived from acid pretreatment and especially to the presence of furfural and HMF (Martin and Jonsson, 2003; Cantarella et al., 2004).

Poor fermentability of dilute acid wood hydrolysates by $S$. cerevisiae correlated to high concentrations of furfural, 5hydroxymethyl furfural and acetic acid (Taherzadeh et al., 1997).

These compounds damage microorganisms by reducing enzymatic and biological activities (Hsu et al., 2010), breaking down DNA, inhibiting protein and RNA synthesis (Khan and Hadi, 1994). The formation of these inhibitors and consequently of toxic compounds has a negative fallout on the rate of enzymatic hydrolysis, which interfere with the subsequent ethanol fermentation. Pentose fermenting microorganisms are generally more inhibited by hemicellulose hydrolysates than hexose fermenting yeasts.

The effect of furfural on cultivation of yeast has been considerable in many studies. Among known effects for batch cultivations are a decrease in the ethanol production rate and specific growth rate. The mode in which furfural inhibit yeast metabolism is not completely known. Though, it has been suggested that furfural inhibits central enzymes in glycolysis, e.g., hexokinase, phosphofructokinase, and triosephosphate dehydrogenase.

\section{Removal of inhibitory by-products formed during pretreatment}

For efficient conversion of sugars to ethanol, removal of these inhibitors from hydrolysate is required.These inhibitors can be avoided to a large extent by optimizing pretreatment conditions for each feedstock. A lot of physical, chemical and biological methods have also been developed to remove or degrade furfural and 5-hydroxyl methyl furfural (HMF) from lignocellulose hydrolysates, such as over-liming, ion exchange, enzymatic conversions and adsorption using active charcoal (Zhang et al., 2010).

Larsson et al. (1999) observed the removal of furfural (90\%) and HMF (4\%) using vacuum evaporation from wood lignocellulosic hydrolysate.Table 2 summarizes the hydrolysate detoxification using various nonbiological methods employed in a variety of lignocellulosichydrolysates. Each method represents its specificity to eliminate particular inhibitor from the hydrolysate.

Due to highly acidic nature of lignocellulosichydrolysates pretreated with dilute acid, neutralization is unavoidable step before using the hydrolysate for fermentation. Alkali, most preferably calcium hydroxide or sodium hydroxide is used for neutralization of hydrolysates (pH-6.0-7.0). During the process, furfurals may be removed by precipitation to some extent.

Over-liming with a combination of high $\mathrm{pH}$ and temperature has for a long time been considered as a promising detoxification method for dilute sulfuric acid-pretreated hydrolysate of lignocellulosic biomass (Chandel et al., 2007), but sugar loss ( 10\%) by adsorption has been demonstrated by this method(Martinez et al., 2001). Chandel et al.,(2007) observed that ion exchange resins 
diminish furans $(63.4 \%)$ and total phenolics (75.8\%) from sugarcane bagasse acid hydrolysates. Although the ion exchange resins are effective, it is not cost effective and reflects its limited feasibility in commercial industrial purpose in lignocellulosics derived products synthesis.

Fig.1 Process of formation of Furfural and HMF from hydrolysis of lignocellulosic biomass Formation of inhibitory by-products during pretreatment

Table.1 Inhibitors profile derived from variety of lignocellulosic materials

\begin{tabular}{|l|l|l|}
\hline \multicolumn{1}{|c|}{$\begin{array}{c}\text { Lignocellulosic } \\
\text { material }\end{array}$} & \multicolumn{1}{|c|}{ Inhibitors profile (g/l) } & \multicolumn{1}{c|}{ References } \\
\hline Rice straw & Acetate, 1.43; HMF, 0.15; Furfural,0.25 & $\begin{array}{l}\text { Baek and Kwon, } \\
2007\end{array}$ \\
\hline Sugarcane bagasse & Furans, 1.89; Phenolics, 2.75; Acetic acid, 5.45 & $\begin{array}{l}\text { Chandel } \text { et al., } \\
2007\end{array}$ \\
\hline Eucalyptus & $\begin{array}{l}\text { Furfural, 0.26; 5-HMF, 0.07; Acetic acid, 3.41; } \\
\text { Phenolics, 2.23 }\end{array}$ & $\begin{array}{l}\text { Villarreal } \text { et al., } \\
2006\end{array}$ \\
\hline
\end{tabular}

Table.2 Strategies applied for detoxification and removal of fermentation inhibitors

\begin{tabular}{|l|l|l|l|}
\hline $\begin{array}{l}\text { Lignocellulosic } \\
\text { Hydrolysate }\end{array}$ & $\begin{array}{l}\text { Detoxification } \\
\text { methods }\end{array}$ & $\begin{array}{l}\text { Changes in hydrolysate } \\
\text { composition }\end{array}$ & References \\
\hline Sugarcane bagasse & Neutralization & Not Applied & Chandel et al., 2007 \\
\hline Oak wood & Activated charcoal & $\begin{array}{l}\text { Removal of phenolics } \\
(95.40 \%)\end{array}$ & Converti et al., 2000 \\
\hline Wheat straw & $\begin{array}{l}\text { Ion exchange-D 311 } \\
\text { + over-liming }\end{array}$ & $\begin{array}{l}\text { Removal of furfurals } \\
(90.36 \%), \text { phenolics } \\
(77.44 \%) \text { and acetic acid } \\
(96.29 \%)\end{array}$ & Zhuang et al., 2009 \\
\hline Wheat straw & $\begin{array}{l}\text { Ethyl acetate + over } \\
\text { liming }\end{array}$ & $\begin{array}{l}\text { Removal of furfurals } \\
(59.76 \%), \text { phenolics } \\
(48.23 \%) \text { and acetic acid } \\
(92.19 \%)\end{array}$ & Zhuang et al., 2009 \\
& & & \\
& & & \\
\hline
\end{tabular}


An alternative route is biological detoxification, which has the advantages of simple operation and less generation of wastes (Zhang et al., 2010). However, the efficiency of biological detoxification is usually low. The highest degradation rates of furfural and HMF were reported to be 0.1 and $0.02 \mathrm{~g} \mathrm{~L}^{-1} \mathrm{~h}^{-1}$, respectively, with detoxification processes taking 1-4 days to complete (Zhang et al., 2010). The low efficiency of biological degradation severely limits its practical applications.

The detoxification of lignocellulosic hydrolysates, by activated charcoal is known to be a cost effective with high capacity to absorb compounds without affecting levels of sugar in hydrolysate (Canilha et al., 2008). The effectiveness of activated charcoal treatment depends on different process variables such as $\mathrm{pH}$, contact time, temperature and the ratio of activated charcoal taken versus the liquid hydrolysate volume (Prakasham et al., 2009). Activated carbon has been reported to remove $96 \%$ of hydroxymethyl furfural (HMF) and $93 \%$ of the furfural in a study by Lee et al. (1999).

As a whole, the appropriate pretreatment conditions play an important role in increasing the efficiency of enzymatic saccharification, thereby making the whole process economically viable. The efficient utilization of soluble sugar content of lignocellulosic biomass is the key for the economic feasibility of ethanol production. Pretreatment temperature, duration and acid concentrations had significant effect on the production of furfural and HMF, which in turn have effect on growth and tolerance level of fermentative microorganism. Presence of inhibitors in lignocellulosic hydrolysate is an industrial malaise. Efficient detoxification of these inhibitors is necessary to increase the ethanol yield from pretreated lignocellulosic hydrolysate before fermentation. Therefore, more efficient detoxification processes need to be developed for industrial applications in lignocellulose biorefinery. The positive impact of low-cost and simple techniques for detoxification such as the use of activated charcoal has also been observed. A clear understanding on the formation of inhibitors and methods of detoxification will go a long way forward in making this biomass waste into a potential source of economically sound and environment-friendly fuel, in order to meet the increasing demand of our growing economy.

\section{References}

Baek, S.C. and Kwon, Y.J. 2007. Optimization of the pretreatment of rice straw hemicellulosichydrolyzates for microbial production of xylitol. Biotechnol.Bioprocess Eng. 12: 404419.

Banerjee, N., Bhatnagar, R. and Viswanathan, L.1981. Inhibition of glycolysis by furfural in Saccharomyces cerevisiae. Eur. J. Appl. Microbiol. Biotechnol. 11: 224-228.

Binod, P., Sindhu, R., Singhania, R.R., Vikram, S., Devi, L., Nagalakshmi, S., Kurien, N., Sukumaran, R.K. and Pandey, A. 2010. Bioethanol production from rice straw: An overview. Biores. Technol. 101: 47674774.

Canilha, L., Carvalho, W., Felipe, M.G.A., and Silva, J.B.A. 2008. Xylitol production from wheat straw hemicellulosichydrolysate:

hydrolysate detoxification and carbon source used for inoculums preparation. Brazilian J. Microbiol.39: 333- 336.

Cantarella, M., Cantarella, L., Gallifuoco, A. and Spera, A. 2004. Effect of inhibitors released during steamexplosion treatment of poplar wood on subsequent enzymatic hydrolysis and 
SSF. Biotechnol.Prog.20: 200-206.

Chandel, A.K., Kapoor, R.K., Singh, A. andKuhad, R.C. 2007. Detoxification of sugarcane bagasse hydrolysate improves ethanol production by Candida shehatae NCIM 3501. Biores. Technol.98: 1947-1950.

Converti, A., Dominguez, J.M., Perego, P., Silva, S.S. and Zilli, M. 2000. Wood hydrolysis and hydrolyzate detoxification for subsequent xylitol production.Chem. Eng.Technol. 23: 1013-1020.

Dien, B.S., Cotta, M.A. and Jeffries, T.W. 2003. Bacteria engineered for fuel ethanol production: current status. Appl. Microbiol. Biotechnol.63: 258266.

Ferrer, E.,Alegria, A., Farre, R., Abellan, P. and Romero, F. 2002. High performance liquid chromatographic determination of furfural compounds in infant formulas: Changes during heat treatment and storage. $J$. Chromatogr. 947: 85-95.

Hahn-Hagerdal, B., Jeppsson, H., Skoog, K. and Prior, B. A., Biochemistry and physiology of xylose fermentation by yeasts.Enzyme Microb.Tech., 16, 933942 (1994).

Hasunuma, T. and Kondo, A. 2012.Development of yeast cell factories for bioethanol production from lignocellulosic materials through synthetic

bioengineering.Biotechnol.Adv. 30(6):1207-1218.

Hsu, T.C., Guo, G.L., Chen, W.H.and Hwang, W.S. 2010.Effect of dilute acid pretreatment of rice straw on structural properties and enzymatic hydrolysis.Biores. Technol.101:49074913.

Khan Q.A. and Hadi S.M. 1994.Inactivation and repair of bacteriophage lambda by furfural.Biochem. Mol. Biol. Int. 32:
379-385.

Larsson, S., Reimann, A., Nilvebrant, N. and Jonsson, L.J. 1999.Comparison of different methods for the detoxification of lignocellulose hydrolysates of spruce.Appl. Biochem. Biotechnol.77: 91-103.

Lee, W.G., Lee, J.S., Shin, C.S., Park, S.C., Chang, H.N. \& Chang, Y.K. (1999) Ethanol production using concentrated oak wood hydrolysates and methods to detoxify. Appl. Biochem. Biotechnol., Vol. 77-79, pp. 547-559.

Luo, C., Brink, D.L. and Blanch, H.W. 2002. Identification of potential fermentation inhibitors in conversion of hybrid poplar hydrolyzate to ethanol.Biomass Bioenergy.22:125-138.

Martin, C. and Jonsson, L.J. 2003. Comparison of the resistance of industrial and laboratory strains of Saccharomyces and Zygosaccharomyces to lignocellulosederived fermentation inhibitors. Enzyme.Microb. Technol. 32: 386395.

Martinez, A., Rodriguez, M.E., Wells, M.L., York, S.W., Preston, J.F. and Ingram, L.O. 2001.Detoxification of dilute acid hydrolysates of lignocellulose with lime.Biotechnol.Prog.17:287293.

Mussatto, S.I. and Roberto, I.C. 2004. Alternatives for detoxification of diluted-acid

lignocellulosichydrolyzates for use in fermentative processes: a review. Biores.Technol. 93:1-10.

Olsson, L. and Hahn-Hagerdal, B. 1996.Fermentation of lignocellulosichydrolysates for ethanol production.Enzyme Microb. Technol.18:312-331.

Prakasham, R.S., Rao, R.S. and Hobbs, P.J. 2009.Current trends in biotechnological production of xylitol 
and future prospects.Curr.Trends Biotechnol. Phar.3:8-36.

Servin, J.L.C., Castellote, A.I. andSabater, M.C.L. 2005.Analysis of potential and freefurfural compounds in milk-based formulae by high performance liquid chromato-graphy evolution during storage. J. Chromatogr.A 1076:133140.

Taherzadeh, M.J., Niklasson, C. and Liden, G. 1997. Acetic acid - friend or foe in anaerobic batch conversion of glucose to ethanol by Saccharomyces cerevisiae.Chem. Eng. Sci.52: 26532659.

Tengborg, C., Stenberg, K., Galbe, M., Zacchi, G., Larsson, S., Palmqvist, E. and Hahn-Hagerdal, B. 1998. Comparison of $\mathrm{SO}_{2}$ and $\mathrm{H}_{2} \mathrm{SO}_{4}$ impregnation of softwood prior to steam pretreatment on ethanol production. Appl. Biochem. Biotechnol.70:3-15.

Tu, D.,Xue, S., Meng, C., Mansilla, A.E., Pena, A.M.D.L. and Lopez, F.S. 1992. Simultaneous determination of 2furfuraldehyde and 5(hydroxymethyl)-2-furfuraldehyde by derivative spectrophotometry. $J$. Agric. Food Chem. 40:1022-1025.

Villarreal, M.L.M. Prata, A.M.R. Felipe, M.G.A. Silva, J.B.A.E. 2006.Detoxification procedures of eucalyptus hemicellulose hydrolysate for xylitol production by Candida guilliermondii.Enzyme Microb. Technol. 40:17-24.

Zaldivar, J., Martinez, A. and Ingram, L.O. 1999. Effect of selected aldehydes on the growth and fermentation of ethanologenicEscherichia coli.Biotechnol.Bioeng. 65:24-33

Zhang, J., Adrian, F.J., Jahnke, W., CowanJacob, S.W., Li, A.G. and Jacob, R.E. 2010. Targeting Bcr-Abl by combining allosteric with ATPbinding-site inhibitors.Nature. 463:501-506.

Zhuang, J., Liu, Y, Wu, Z., Sun, Y. and Lin, L. (2009) Hydrolysis of wheat straw hemicellulose and detoxification of the hydrolysate for xylitol production.BioResources, Vol. 4, pp. 674-686.

\section{How to cite this article:}

Mahesh Kumar Malav, Shiv Prasad, Sushil Kumar Kharia, Sandeep Kumar, K.R. Sheetal and Sudha Kannojiya. 2017. Furfural and 5-HMF: Potent fermentation inhibitors and their removal techniques. Int.J.Curr.Microbiol.App.Sci. 6(3): 2060-2066.

doi: https://doi.org/10.20546/ijcmas.2017.603.235 